\title{
An Empirical Study on R\&D Investment and Financial Performance of Listed Companies in Liaoning Equipment Manufacturing Industry*
}

\author{
Kaiming Tan \\ School of Economics and Management \\ Dalian University \\ Dalian, China
}

\author{
Shihong Wei \\ School of Economics and Management \\ Dalian University \\ Dalian, China
}

\begin{abstract}
Technological progress is the core of corporate economic growth, and R\&D investment activities are the basis of technological innovation. In the context of the country's implementation of the innovation-driven strategy, the company's innovation input performance has become a research hotspot. This paper takes the financial data of Liaoning equipment manufacturing listed companies from 2015 to 2017 as the research object, and conducts empirical analysis on the relationship between $R \& D$ investment and financial performance. Under the enlightenment of previous studies, this paper takes the relationship between R\&D investment and corporate financial performance as the research goal, and selects five representative financial indicators from profit, growth, operation and solvency, and uses correlation analysis. The model of $R \& D$ investment and financial performance of Liaoning equipment manufacturing industry was constructed, and the financial data of 18 listed equipment manufacturing enterprises in Liaoning were used for empirical analysis. The analysis results show that $R \& D$ investment is conducive to improving corporate financial performance, and $R \& D$ investment has a lag in return to the enterprise. And there is hysteresis based on the conclusions of the above studies.
\end{abstract}

Keywords-equipment manufacturing industry; R\&D input; financial performance

\section{INTRODUCTION}

One of the main tasks of the Liaoning Free Trade Zone is to promote industrial transformation and upgrading, and to build an industrial layout integrating the development of advanced equipment manufacturing, strategic emerging industries and modern service industries. Therefore, it is very important to improve the overall innovation capability and business performance of Liaoning equipment manufacturing industry. Hu, A.G., and Jefferson (2003) came to an inconspicuous conclusion when choosing the size of the firm as the research object. Therefore, there is no significant connection between the size of the company and its financial performance. Ren Haiyun, Shi Ping (2009), based on the

*Fund: This work was supported by Science and Technology Project of Dalian City (2018J14FZ138) and Science and Technology Project of Jinpu New Area 2017 and Doctoral Fund Project of DLU 2019. (Project No.: 20182QL006) sample of manufacturing listed companies, concluded that there was a positive correlation between $R \& D$ investment and main business income, and there was no lag period. Liang Laiyi and Zhang Huanfeng (2005) took 72 listed companies as samples. Research shows that $R \& D$ investment has a positive effect on the improvement of financial indicators and has a delayed effect on financial performance.

Based on this, this paper takes Liaoning equipment manufacturing industry as the research object, and aims at the relationship between $R \& D$ investment and financial performance, the combination of theoretical deduction and empirical research. According to the theoretical mechanism of $\mathrm{R} \& \mathrm{D}$ investment and financial performance, this paper selects $R \& D$ investment indicators, finance performance indicators, puts forward relevant assumptions on the basis of theory, establish models, and conducts Pearson correlation test on financial data. Based on the above analysis conclusions, the paper puts forward corresponding suggestions for the development of Liaoning equipment manufacturing industry.

\section{EMPIRICAL RESEARCH DESIGN}

\section{A. Relevant Assumptions}

$\mathrm{R} \& \mathrm{D}$ investment can improve the level of enterprise product technology, reduce production costs, and increase labor productivity, which plays an important role in improving the performance of enterprises. This paper believes that in the equipment manufacturing listed companies, $\mathrm{R} \& \mathrm{D}$ investment is the independent variable, and the financial performance indicator is the dependent variable. There is a positive correlation between $R \& D$ investment and financial performance. The benefits of $R \& D$ inputs can be summarized as follows:

- R\&D investment can increase labor productivity and reduce production costs. If the strategy of no technology and low cost is adopted, the enterprise will be in danger, and relying on innovative productivity, continuous technological innovation, and increasing the intensity of R\&D investment will 
TABLE I. SAMPLE ENTERPRISES

intermediate links, and increase corporate income.

- The differentiated competition strategy is to form a differentiated advantage in the market competition and increase the customer's attention. By increasing $\mathrm{R} \& \mathrm{D}$ investment, we will expand product categories, improve product quality, and differentiate from other products.

This paper examines the impact of profitability, growth, operational and solvency on financial performance.

Based on the above analysis, the following assumptions are made:

Hypothesis 1: R\&D investment is positively correlated with profitability indicators.

Hypothesis 2: R\&D investment is positively correlated with growth performance indicators.

Hypothesis 3: R\&D investment is positively correlated with operational capability indicators.

Hypothesis 4: R\&D inputs are positively correlated with solvency indicators.

The R\&D investment of the company is continuous. The early $R \& D$ is the basis of the late $R \& D$, and the $R \& D$ activities take a long time. Related studies have shown that the impact of R\&D investment on financial performance has a lagging effect. Therefore, the current financial performance of the company is affected by the previous n-phase $R \& D$ investment.

\section{B. Sample Selection and Data Source}

This paper studies the sample of the listed companies in Liaoning equipment manufacturing industry, through the listing of annual reports of listed companies, find the relevant data of R\&D activities, and analyze the relationship between R\&D input and financial performance. The following screening procedures were performed:

According to the industry classification standards promulgated by the China Securities Regulatory Commission in 2017, refer to the latest data released by the website in 2017 to determine the listed companies in the manufacturing industry. There are 76 listed companies in Liaoning Province, including 42 manufacturing industries. From Shanghai Stock Exchange and Shenzhen Stock Exchange A-share market, 20 listed companies of equipment manufacturing industry in Liaoning Province are selected as the research objects, and the financial statements of these enterprises in 2017, 2016, 2015 are taken as the data sources.

\section{Remove ST Company.}

Considering lag and persistence, 2017 study requires R\&D inputs in 2015, 2016 and 2017 as independent variables, excluding companies that lack R\&D investment in any year from 2015 to 2017, and finally obtain 18 available samples. Excel2010, SPSS24.0 statistical software is mainly used to process the data. (See "Table I")

\begin{tabular}{|c|c|c|c|}
\hline $\begin{array}{l}\text { Stock } \\
\text { code }\end{array}$ & $\begin{array}{l}\text { Name of } \\
\text { securities }\end{array}$ & $\begin{array}{l}\text { Stock } \\
\text { code }\end{array}$ & Name of securities \\
\hline sz002487 & $\begin{array}{l}\text { Dalian Huarui } \\
\text { Heavy Industry } \\
\text { Group Co., Ltd. }\end{array}$ & sz002204 & $\begin{array}{l}\text { Dalian } \\
\text { Heavy } \\
\text { Group Co., Ltd. }\end{array}$ \\
\hline sh603315 & $\begin{array}{l}\text { Liaoning Fu-An } \\
\text { Heavy Industry } \\
\text { Co., Ltd. }\end{array}$ & sz002621 & $\begin{array}{ll}\text { Dalian My } & \text { Gym } \\
\text { Education } & \\
\text { Technology } & \text { Co., } \\
\text { Ltd. } & \end{array}$ \\
\hline sz000530 & $\begin{array}{l}\text { Dalian } \\
\text { Refrigeration } \\
\text { Co., Ltd. }\end{array}$ & sz002667 & $\begin{array}{l}\text { Anshan Heavy Duty } \\
\text { Mining Machinery } \\
\text { Co., Ltd. }\end{array}$ \\
\hline sz002689 & $\begin{array}{l}\text { Shenyang } \\
\text { Yuanda } \\
\text { Intellectual } \\
\text { Industry Group } \\
\text { Co., Ltd. }\end{array}$ & sz300210 & $\begin{array}{l}\text { Anshan Senyuan } \\
\text { Road \& Bridge Co., } \\
\text { Ltd }\end{array}$ \\
\hline sz300024 & $\begin{array}{l}\text { Siasun Robot } \\
\text { and Automation } \\
\text { Company } \\
\text { Limited }\end{array}$ & sz300293 & $\begin{array}{lr}\text { Shenyang } & \text { Blue } \\
\text { Silver } & \text { Industry } \\
\text { Automatic } & \\
\text { Equipment Co., Ltd }\end{array}$ \\
\hline sz300097 & $\begin{array}{l}\text { Dalian Zhiyun } \\
\text { Automation } \\
\text { Co., Ltd. }\end{array}$ & $\begin{array}{l}\text { sh } 60030 \\
3\end{array}$ & $\begin{array}{l}\text { Liaoning SG } \\
\text { Automotive Group } \\
\text { Co., Ltd. }\end{array}$ \\
\hline sz300202 & $\begin{array}{l}\text { Lianyungang } \\
\text { Ideal Group } \\
\text { Co., Ltd. }\end{array}$ & $\begin{array}{l}\operatorname{sh} 60060 \\
9\end{array}$ & $\begin{array}{l}\text { Shenyang Jinbei } \\
\text { Automotive } \\
\text { Company Limited }\end{array}$ \\
\hline sz300473 & $\begin{array}{l}\text { Fuxin Dare } \\
\text { Automotive } \\
\text { Parts Co., Ltd. }\end{array}$ & sz002606 & $\begin{array}{l}\text { Dalian Insulator } \\
\text { Group Co., Ltd. }\end{array}$ \\
\hline sh603318 & $\begin{array}{l}\text { Dalian Energas } \\
\text { Gas-System } \\
\text { Co., Ltd. }\end{array}$ & sz002231 & $\begin{array}{l}\text { Allwin } \\
\text { Telecommunication } \\
\text { Co. Ltd }\end{array}$ \\
\hline
\end{tabular}

\section{Indicator Variable Selection}

1) Indicator variable selection: The input intensity of $\mathrm{R} \& \mathrm{D}$ is the most widely used index to measure the input of $\mathrm{R} \& \mathrm{D}$, which is expressed by the radio of the total input of $\mathrm{R} \& \mathrm{D}$ to the income of the main business. Compared with the total index, the R\&D input intensity better reflects the enterprise scale and market position, and is more comparable among different enterprises.

\section{2) Selection of dependent variables}

a) Selection of profitability index: As a common comprehensive indicator for judging the profitability of listed companies, the rate of return on net assets is the ratio of the company's after-tax profits to net assets, which is used to measure the efficiency of using its own capital. Therefore, the profitability performance indicators used in this paper mainly include: return on net assets, and gross profit margin.

b) Selection of growth ability indexes: The growth rate of the operating income reflected the change of the company's operating income and can better measure the growth of the company. Therefore, the growth capacity performance index selected in this paper is the growth rate of operating income. The growth performance indicator selected in this paper is the operating income growth rate. 
will result in different willingness to invest in $R \& D$, high asset-liability ratio, cautious consideration, low investment willingness, low asset-liability ratio, low debt repayment pressure, and willingness to invest. Therefore, the second control variable selected in this paper is the debt-to-debt radio.

4) Model design: The empirical research on $\mathrm{R} \& \mathrm{D}$ input and financial performance generally adopts the methods of correlation analysis and regression analysis. In this paper, multiple regression analysis is used to determine the input intensity of R\&D in 2015, 2016 and 2017 as independent variables; the dependent variable is the rate of return of net assets, gross interest rate, operating income growth rate, total assets turnover rate and operating cash flow. There is continuity and correlation between $\mathrm{R} \& \mathrm{D}$ input in the current period and the next two periods, and the financial index of three years is more scientific in the construction of the model. If the independent variable is the current $R \& D$ input and the dependent variable is the financial index for three consecutive years, it is impossible to determine whether the change of the financial index is caused by the current $R \& D$ input.

The specific models are as follows:

Model 1: multiple regression Model between R\&D input intensity and profitability

the natural logarithm of total assets. The asset-liability ratio is an index to measure the company's financial risk, which

$$
\begin{gathered}
R O E=\alpha_{0}+\alpha_{1} A R D_{2015}+\alpha_{2} A R D_{2016}+\alpha_{3} A R D_{2017}+\alpha_{4} S I Z E+\alpha_{5} A L R+\theta \\
G P M=\alpha_{0}+\alpha_{1} A R D_{2015}+\alpha_{2} A R D_{2016}+\alpha_{3} A R D_{2017}+\alpha_{4} S I Z E+\alpha_{5} A L R+\theta
\end{gathered}
$$

Model 2: multiple regression Model between R\&D input intensity and growth ability

$$
I R=\alpha_{0}+\alpha_{1} A R D_{2015}+\alpha_{2} A R D_{2016}+\alpha_{3} A R D_{2017}+\alpha_{4} S I Z E+\alpha_{5} A L R+\theta
$$

Model 3: multiple regression Model between input intensity and operating capacity of $\mathrm{R} \& \mathrm{D}$

$$
T A T=\alpha_{0}+\alpha_{1} A R D_{2015}+\alpha_{2} A R D_{2016}+\alpha_{3} A R D_{2017}+\alpha_{4} S I Z E+\alpha_{5} A L R+\theta
$$

Model 4: multiple regression Model between R\&D input intensity and solvency

$$
C F R=\alpha_{0}+\alpha_{1} A R D_{2015}+\alpha_{2} A R D_{2016}+\alpha_{3} A R D_{2017}+\alpha_{4} S I Z E+\alpha_{5} A L R+\theta
$$

Variable explanation:ARD2015 represents the input intensity of R\&D in 2015; ARD2016 represents R\&D input strength in 2016; ARD2017 represents 2017 R\&D input intensity; ROE represents the return on net assets in 2017; GPM represents gross profit rate in 2017; IR represents the growth rate of operating income in 2017; TAT represents the total asset turnover of 2017; CFR represents the operating cash flow ratio for 2017; both SIZE and ALR are controlled variables; SIZE represents the size of the company; ALR represents the asset-liability ratio; $\theta$ is a random error term.

\section{THE EMPIRICAL ANALYSIS OF R\&D INVESTMENT AND CORPORATE FINANCIAL PERFORMANCE}

\section{A. Descriptive Analysis}

The financial performance of listed companies in Liaoning equipment manufacturing industry has a big difference. "Table II" lists the statistical analysis results of the main variables. Among them, there are large changes in GPM, IR and CFR. The average sample size of IR is $74.0706 \%$, but the minimum value is $-26.55 \%$, and the maximum value is $643.14 \%$. The difference between the two is $660.69 \%$, indicating that the IR rate is uneven, so the future growth capacity is the focus of the company. 
TABLE II. DESCRIPTIVE STATISTICAL ANALYSIS

\begin{tabular}{|c|l|l|l|l|l|}
\hline & Minimum value & \multicolumn{1}{|c|}{ Maximum value } & \multicolumn{1}{|c|}{ Average value } & Standard deviation & Number of samples \\
\hline ARD2017 & $0.18 \%$ & $25.01 \%$ & $5.7800 \%$ & $5.49453 \%$ & 18 \\
\hline ARD2016 & $1.29 \%$ & $19.27 \%$ & $6.5833 \%$ & $5.30662 \%$ & 18 \\
\hline ARD2015 & $1.26 \%$ & $13.28 \%$ & $5.5644 \%$ & $3.73687 \%$ & 18 \\
\hline ROE & $-1.04 \%$ & $13.87 \%$ & $5.1911 \%$ & $4.19294 \%$ & 18 \\
\hline GPM & $14.40 \%$ & $46.34 \%$ & $29.5278 \%$ & $11.18464 \%$ & 18 \\
\hline IR & $-26.55 \%$ & $643.14 \%$ & $74.0706 \%$ & $163.31114 \%$ & 18 \\
\hline TAT & $0.04 \%$ & $0.82 \%$ & $0.4006 \%$ & $0.20947 \%$ & 18 \\
\hline CFR & $-30.65 \%$ & $78.36 \%$ & $4.7283 \%$ & $23.79692 \%$ & 18 \\
\hline ALR & $11.82 \%$ & $85.41 \%$ & $41.0450 \%$ & $18.74148 \%$ & 18 \\
\hline SIZE & 20.59694745 & 23.44873648 & 21.77560652 & 0.78593385 & 18 \\
\hline
\end{tabular}

From the independent variables in "Table II", the intensity of R\&D investment is constantly changing, and companies are paying more and more attention to $R \& D$ investment. The average R\&D input intensity in 2015 was $5.5644 \%$, with a minimum of $1.26 \%$ and a maximum of $13.28 \%$; the average R\&D input intensity in 2016 was $6.5383 \%$, with a minimum of $1.29 \%$ and a maximum of $19.27 \%$. The average $\mathrm{R} \& \mathrm{D}$ input intensity in 2017 was $5.78 \%$, with a minimum of $0.18 \%$ and a maximum of $25.01 \%$. The standard deviation of enterprises rose from $3.73687 \%$ in 2015 to $5.49453 \%$ in 2017 . This shows that the input intensity of different companies varies greatly.

As can be seen from "Table II", as a control variable, the sample mean of ALR is $41.0450 \%$, the minimum value is $11.82 \%$, and the maximum value is $85.41 \%$. This shows that the difference in the industry and scale of operations has caused a huge difference in asset-liability ratio, so the assetliability ratio and company size are used as control variables.

\section{B. Correlation Analysis}

1) Correlation analysis between $R \& D$ investment and profitability: The correlation analysis between $\mathrm{R} \& \mathrm{D}$ input intensity and ROE and GPM between 2015 and 2017 is shown in "Table III" and "Table IV". From the correlation analysis in "Table III", it can be concluded that ROE has a negative correlation with the R\&D input intensity in 2015 . The correlation coefficient between $R \& D$ input intensity and ROE in 2015 was -0.492 , and the correlation level passed the 0.05 test. Therefore, although there is no positive correlation between ROE and R\&D input intensity, there is a correlation between the two.

TABLE III. CORRELATION ANALYSIS BETWEEN R\&D INPUT INTENSITY AND RETURN ON NET ASSETS

\begin{tabular}{|l|l|l|l|l|l|l|l|}
\hline \multicolumn{2}{|c|}{} & ARD2017 & ARD2016 & ARD2015 & ROE & ALR & SIZE \\
\hline ARD2017 & Pearson correlation & 1 & $.693^{* *}$ & $.641^{* *}$ & -.419 & $-.594^{* * *}-.285$ \\
\hline ARD2016 & Pearson correlation & $.693^{* *}$ & 1 & $.970^{* *}$ & -.422 & $-.470^{*}$ & -.450 \\
\hline ARD2015 & Pearson correlation & $.641^{* *}$ & $.970^{* *}$ & 1 & $-.492^{*}$ & -.404 & -.421 \\
\hline ROE & Pearson correlation & -.419 & -.422 & $-.492^{*}$ & 1 & .354 & .264 \\
\hline ALR & Pearson correlation & $-.594^{* *}$ & $-.470^{*}$ & -.404 & .354 & 1 & $.576^{*}$ \\
\hline SIZE & Pearson correlation & -.285 & -.450 & -.421 & .264 & $.576^{*}$ & 1 \\
\hline
\end{tabular}

TABLE IV. CORRELATION ANALYSIS BETWEEN R\&D INPUT INTENSITY AND GRoss PROFIT MARGIN

\begin{tabular}{|l|l|l|l|l|l|l|l|}
\hline & & ARD2017 & ARD2016 & ARD2015 & ROE & ALR & SIZE \\
\hline ARD2017 & Pearson correlation & 1 & $.693 * *$ & $.641^{* *}$ & -.419 & $-.594 * *$ & -.285 \\
\hline ARD2016 & Pearson correlation & $.693^{* *}$ & 1 & $.970^{* *}$ & -.422 & $-.470^{*}$ & -.450 \\
\hline ARD2015 & Pearson correlation & $.641^{* *}$ & $.970^{* *}$ & 1 & $-.492 *$ & -.404 & -.421 \\
\hline ROE & Pearson correlation & -.419 & -.422 & $-.492^{*}$ & 1 & .354 & .264 \\
\hline ALR & Pearson correlation & $-.594 * *$ & $-.470^{*}$ & -.404 & .354 & 1 & $.576^{*}$ \\
\hline SIZE & Pearson correlation & -.285 & -.450 & -.421 & .264 & $.576^{*}$ & 1 \\
\hline
\end{tabular}

From the correlation analysis in "Table IV", it can be obtained that GPM is positively correlated with 2016 R\&D input intensity and 2017 R\&D input intensity. The correlation coefficient between $R \& D$ input intensity and GPM in 2017 is 0.483; the correlation coefficient between R\&D input intensity and GPM in 2016 is 0.474 ; the correlation coefficient between R\&D input intensity and GPM in 2015 is 0.396. 2016 and 2017 the correlation between R\&D input intensity and GPM was significantly tested by a 0.05 test. Therefore, the research results show that there is a significant positive correlation between $R \& D$ investment and the profitability of the company, and there is a lag period.

2) Analysis of the correlation between $R \& D$ investment and growth ability: The correlation analysis of $\mathrm{R} \& \mathrm{D}$ input intensity and IR between 2015 and 2017 is shown in "Table $\mathrm{V}^{\prime \prime}$. 
TABLE V. CORRELATION ANALYSIS BETWEEN R\&D INPUT INTENSITY AND OPERATING INCOME GROWTH RATE

\begin{tabular}{|l|l|l|l|l|l|l|l|}
\hline & & ARD2017 & ARD2016 & ARD2015 & ROE & ALR & SIZE \\
\hline ARD2017 & Pearson correlation & 1 & $.693^{* *}$ & $.641^{* *}$ & -.419 & $-.594^{* *}$ & -.285 \\
\hline ARD2016 & Pearson correlation & $.693^{* *}$ & 1 & $.970^{* *}$ & -.422 & $-.470^{*}$ & -.450 \\
\hline ARD2015 & Pearson correlation & $.641^{* *}$ & $.970^{* *}$ & 1 & $-.492^{*}$ & -.404 & -.421 \\
\hline ROE & Pearson correlation & -.419 & -.422 & $-.492^{*}$ & 1 & .354 & .264 \\
\hline ALR & Pearson correlation & $-.594^{* *}$ & $-.470^{*}$ & -.404 & .354 & 1 & $.576^{*}$ \\
\hline SIZE & Pearson correlation & -.285 & -.450 & -.421 & .264 & $.576^{*}$ & 1 \\
\hline
\end{tabular}

From the correlation analysis in "Table V", IR is positively correlated with the R\&D input intensity in 2015 and the R\&D input intensity in 2016. The correlation coefficient between R\&D input intensity and IR in 2017 is 0.016; the correlation coefficient between $R \& D$ input intensity and IR in 2016 is 0.522 ; the correlation coefficient between R\&D input intensity and IR in 2015 is 0.593 . R\&D 2015, 2016 the significant level of correlation between input intensity and IR passed the 0.05 test. The correlation of IR to R\&D input intensity has increased year by year, and the two periods are most significant. Therefore, the results of the study indicate that there is a significant positive correlation between R\&D investment and the growth capacity of the company, with a lag period of two years.

3) Correlation analysis between $R \& D$ investment and operational capability: The correlation analysis between R\&D input intensity and TAT between 2015 and 2017 is shown in "Table VI".

\section{TABLE VI. CORRELATION ANALYSIS BETWEEN R\&D INPUT INTENSITY AND TOTAL ASSET TURNOVER}

\begin{tabular}{|c|c|c|c|c|c|c|c|}
\hline & & ARD2017 & ARD2016 & ARD2015 & ROE & ALR & SIZE \\
\hline ARD2017 & Pearson correlation & 1 & $.693 * *$ & $.641 * *$ & -.419 & $.594 * *$ & -.285 \\
\hline \begin{tabular}{|l|} 
ARD2016 \\
\end{tabular} & Pearson correlation & $.693 * *$ & 1 & $.970^{* *}$ & -.422 & $-.470 *$ & -.450 \\
\hline ARD2015 & Pearson correlation & $.641 * *$ & $.970 * *$ & 1 & $-.492 *$ & -.404 & -.421 \\
\hline ROE & Pearson correlation & -.419 & -.422 & $-.492 *$ & 1 & .354 & .264 \\
\hline ALR & Pearson correlation & $-.594 * *$ & $-470^{*}$ & -.404 & 354 & 1 & $576^{*}$ \\
\hline SIZE & Pearson correlation & -.285 & -.450 & -.421 & .264 & $.576^{*}$ & \\
\hline
\end{tabular}

From "Table VI", the correlation coefficient between R\&D input intensity and TAT between 2015 and 2017 is negative. Only the R\&D input intensity in 2017 has a correlation with TAT, and the correlation coefficient is 0.598 . Therefore, it does not prove that there is a correlation between R\&D input intensity and TAT, and there is no obvious correlation between R\&D investment and solvency.

$$
\begin{aligned}
& \text { b. } * * \text {. At the } 0.01 \text { level(Two-tailed),Significant correlation } \\
& \text { b. *. At the } 0.05 \text { level(Two-tailed),Significant correlation }
\end{aligned}
$$

4) Correlation analysis between $R \& D$ investment and solvency: The correlation analysis between R\&D input intensity and CFR between 2015 and 2017 is shown in "Table VII".

TABLE VII. CORRELATION ANALYSIS BETWEEN R\&D INPUT INTENSITY AND OPERATING CASH FLOW RATIO

\begin{tabular}{|l|l|l|l|l|l|l|l|}
\hline \multicolumn{2}{|c|}{} & ARD2017 & ARD2016 & ARD2015 & ROE & ALR & SIZE \\
\hline ARD2017 & Pearson correlation & 1 & $.693^{* *}$ & $.641^{* *}$ & -.419 & $-.594^{* *}$ & -.285 \\
\hline ARD2016 & Pearson correlation & $.693^{* *}$ & 1 & $.970^{* *}$ & -.422 & $-.470^{*}$ & -.450 \\
\hline ARD2015 & Pearson correlation & $.641^{* *}$ & $.970^{* *}$ & 1 & $-.492^{*}$ & -.404 & -.421 \\
\hline ROE & Pearson correlation & -.419 & -.422 & $-.492^{*}$ & 1 & .354 & .264 \\
\hline ALR & Pearson correlation & $-.594^{* *}$ & $-.470^{*}$ & -.404 & .354 & 1 & $.576^{*}$ \\
\hline SIZE & Pearson correlation & -.285 & -.450 & -.421 & .264 & $.576^{*}$ & 1 \\
\hline
\end{tabular}

From "Table VII", the correlation coefficient between R\&D input intensity and CFR in $2015-2017$ is positive, but they have not passed the significant test of 0.01 , which is statistically meaningless. R\&D investment and corporate solvency have not shown obvious relationship.

\section{CONCLUSION}

Through descriptive analysis and correlation analysis of sample data of listed companies in Liaoning equipment manufacturing industry from 2015 to 2017 , the following conclusions are drawn:

$\mathrm{R} \& \mathrm{D}$ investment is conducive to improving the profitability and growth capacity of enterprises. The research results show that $R \& D$ investment has a significant impact on the gross profit rate and revenue growth rate. An enterprise is a profit-oriented market subject, and its decision-makers attach importance to $R \& D$ activities that are conducive to improving financial performance. $R \& D$ results 
can help enterprises reduce production costs, improve market share, continuously launch new products and shorten the time from input to output of new products. The products with high technical content are not easy to be imitated and replaced, which makes the enterprise take the lead in the fierce market competition.

The effect of $R \& D$ investment on financial performance is lagging behind. $R \& D$ investment has a lag in the return of enterprises, sometimes the income is not available in the current period. For lagging problems, enterprises should treat them correctly. They should not only invest in projects with short-term returns, but also encourage enterprises to adhere to $\mathrm{R} \& \mathrm{D}$ investment so as to gain core advantages and sustainable development ability.

\section{REFERENCES}

[1] Jiang Yu-han, Luo Yang-mei, Yun Rui-li. Research on the Correlation between Green Innovation Investment and Financial Performance in Automobile Manufacturing Enterprises [J]. Accounting and Finance.2018(01).

[2] Zhang Tao, Yao Jieyun. Does R\&D Intensity Influence Enterprises' Development Ability and Profitability? [J]. Journal of Shandong University of Finance and Economics. 2017(01).

[3] Qiu Yuxing, Yu Xiyang, Yao Yuying. Management Incentive, R\&D Investment and Enterprise Performance - Based on the Empirical Analysis of State-owned Listed Companies [J]. Friends of Accounting.2017(12).

[4] Wen Ruolin. Study of the Influence on the Performance of the Company into the R\&D - In the Beijing Tianjin Hebei Region Manufacturing Industry Listing Corporation As an Example [D]. Hebei University of Economics and Business. 2015.

[5] Gamer, Nam and Ottot Growth Opportunities of Eme Firms. Joumal of Eeconomies and Business. 2002(03).

[6] Hu, A.G and Jefferson. A Dyamic View of Strategy [J]. Sloan Management Review, 2003(14).

[7] Ren Haiyu, Shi Ping. An Empirical Research on the Relationship between R\&D Expenditure and Firm Performance [J]. Science \& Technology Progress and Policy. 2009(24).

[8] Lu Yumei, Wang Chunmei. Effect of R\&D Investment on Performance of Chinese Listed Companies - Take Manufacturing and IT Industry as an Example [J]. Science and Technology Management Research. 2011(05). 